\title{
Restructuring in manufacturing: case studies of Chile, Mexico and Venezuela
}

\section{Carla Macario}

ECLAC Division of

Production, Productivity

and Management.
The economies of Latin America have undergone important transformations during the past years. Yet, while there have been many studies on the macroeconomic changes that have taken place in Latin America, studies on the microeconomic changes are relatively scarce. The purpose of this paper is to provide evidence that leads to a better understanding of how firms respond to new circumstances. The research on Latin American manufacturing firms presented here shows that the new state of the economic environment has led to a substantial change in firms' behaviour. Innovative firms have adopted flexible forms of behaviour and are upgrading their production and marketing capabilities, and they have introduced significant changes in terms of vertical integration, input procurement, technological innovation, incentive pay systems and management techniques, training, subcontracting, distribution and retailing. At least for the most innovative consumer goods manufacturing firms, their core activities have shifted from being mainly concerned with production to combining the manufacture of goods with their distribution, and often also the distribution of other domestic and imported goods as well. This provides them with a better chance of simultaneously increasing their profits and defending their market share. Finally, the investigation also showed that uncertainty surrounding economic policy leads to a substantial decrease in investment by firms. Such uncertainty explains why more firms do not change, or why they do not change faster. It has a twofold negative effect on entrepreneurs' decisions to modernize their firms: they are uncertain about what they should do, as well as about the sustainability of the economic policy. There is therefore an important role for policies that redound in programmes that seek to encourage firms to upgrade. At the same time, it must be stressed that the most important role for policy is that of creating a stable economic environment in which firms can plan long-term investment. 


\title{
I
}

\section{Introduction}

The countries of Latin America have undergone important transformations in the past few years. There have been radical changes in macroeconomic and trade policies and in the general economic environment, such as in matters relating to State intervention and the regulatory framework, accompanied by increased globalization of world markets. As a result, there have been important changes at the macroeconomic level and in the way the economies of the region relate to the world economy, as well as in the behaviour of firms.

While there have been many studies on the macroeconomic changes that have taken place in Latin America, studies on the microeconomic changes are relatively scarce. One of the first of these studies examined how Chilean firms adapted to such changes during the 1970s and early 1980s (Corbo and Sánchez, 1984). In recent years, along with a consensus in most countries on what macroeconomic policies should be adopted to achieve long-term stability, there has been a growing interest in research into changes in manufacturing companies' behaviour and the way they are adapting to the new economic environment (Baumann, 1994; Bielschowsky, 1994; Castillo, Dini and Maggi, 1994; Katz and Burachik, 1997).

This paper presents the results of an investigation into manufacturing firms' strategies and changes in these strategies as a result of trade liberalization, globalization, and transformations in the economic environment in which they operate. The main questions this research set out to answer were the following: Are Latin American firms in traditional consumer goods manufacturing sectors changing their strategies, or are they for the most part functioning as they did 20 years ago? How decisive is the influence of macroeconomic events on microe- conomic ones, and what is the margin that companies have for individual behaviour? If traditional consumer goods manufacturing firms' behaviour is changing, what are the most important areas in which these changes are taking place? What are the strategies of the firms in these industries that are most advanced in the modernization process in the region?

This investigation was carried out in mediumsized and large traditional consumer goods manufacturing firms in Chile, Mexico and Venezuela. From the beginning, it was decided to focus mainly on such firms, since it was assumed that they were among the most representative of the medium-sized and large manufacturing firms that could be found in all three countries. The sectors included covered a wide range of industries but strongly emphasized garment firms, as a way of comparing the behaviour of firms across countries in comparable industries, because garment manufacturers belong to an industry that was established several decades ago, not only in the countries included in the research, but in most other Latin American countries as well. It was also interesting to study this industry because it has been strongly exposed to competition from imports and has been strongly affected by the globalization of the garment sector worldwide.

Over 40 garment firms were included in the study, although comparable data were only available for 38 of them: ${ }^{1}$ hence, the conclusions presented in this article are inferred mainly from this type of firm. ${ }^{2}$ Interviews with executives of the firms on the basis of open-ended questionnaires were complemented with plant visits, as well as with meetings with trade association representatives, industry experts and government officials. Firms were chosen so as to provide a diversity of companies, but it is not claimed that they make up a representative sample. Most of the

\footnotetext{
${ }^{1}$ See Macario (1998a).

${ }^{2}$ However, they appear to be valid for other traditional consumer goods manufacturing firms, such as those in the footwear and leather industries (see Macario, 1998b).
}

$\square$ The author wishes to thank Ricardo Bielschowsky, Jorge Katz and Joseph Ramos for their many valuable comments that led to this paper. The basic research was carried out as part of the ECLAC/UNDP Project on Innovation and Competitiveness. ECLAC staff members Wilson Peres, Martine Guerguil and the author herself carried out the interviews.

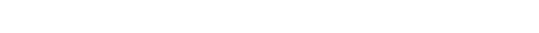


interviews took place in 1993, but some were conducted in 1994 and 1995. In some cases, the initial interviews were supplemented by follow-up visits, so as to obtain a better perspective of changes in company strategy over time.

The following section of this paper (section II) describes the main characteristics of the behaviour of traditional consumer goods manufacturing firms under import substitution. It is partly based on the same interviews with the executives, who were questioned about the history of their firm. Section III presents the main findings of the research concerning the be- haviour of traditional consumer goods manufacturing firms in the process of modernization, and the last section (section IV) presents the main conclusions.

Finally, a warning is in order: while there are many different definitions of competitiveness and indicators for measuring it, in this paper the term "competitive" is used as a synonym of "modernizing": when a company is described as being competitive, this should be understood as meaning that it is an innovative firm, striving for survival and change and trying to find the most appropriate ways to adapt to a new environment and thereby increase its market share.

\section{II}

\section{Company behaviour under import substitution}

What are the main strategies of a firm manufacturing consumer goods under import substitution? This section tries to answer this question by describing the main features of the evolution of a representative firm.

The typical firm interviewed in this survey is a family company that was initially set up in a small workshop in sectors such as garment or shoe production, or a small metal-casting plant. This small workshop slowly expanded, buying new equipment, moving to new premises and becoming an authentic manufacturing firm.

The transition from small workshop to manufacturing plant was often quite difficult and risky, in the face of competition from many other similar workshops. Financial assistance for small firms was generally not available, so that one of the critical factors in the transition was the ability to accumulate enough financial resources to expand. Hence, very few workshops were able to be become manufacturing firms unless the entrepreneurs were successful in obtaining sufficient funds, often thanks to family support, lobbying with government agencies, or sheer luck.

Production was generally initially organized along the same lines as in the workshop, slowly evolving subsequently into a pattern broadly based on the organization of work in plants in industrialized countries.

Plant layout was often designed by the entrepreneur himself. The firm manufactured a wide variety of products with unsophisticated design and quality standards. This was good enough for a growing body of consumers who were just beginning to have access to manufactured goods and were therefore not very demanding.

Management was generally the responsibility of family members and did not follow professional criteria. Production workers were paid fixed wages or, in some cases, were on piecework, without strict quality requirements. Firms did not provide training.

Most production operations were carried out internally in the firm. Subcontracting was very rare and was only used for very specific operations that were difficult to carry out in the plant itself, or to satisfy unexpected surges in demand.

In general, inputs were manufactured within the country, in view of the prevailing import substitution policies, as well as the costs and delays involved in importing them from abroad. Larger firms tended to be vertically integrated, manufacturing inputs not only for their own use but also to sell to other domestic firms. There was a powerful incentive for firms to become as integrated as possible, since companies selling intermediate goods were often rivals in the finished product market.

Most goods produced were sold on the domestic market. It was generally difficult for consumer goods manufacturers to export on a regular basis for a number of reasons, such as the anti-export bias result- 
ing from high tariffs or from non-tariff barriers; the relatively low level of the exchange rate in most countries throughout nearly all of the import substitution period; and the very high transportation costs within the region.

Tariff and non-tariff barriers in other Latin American countries which could have been among the most attractive markets also helped to make exporting less appealing. Protectionism and transport costs made it difficult to export to the industrialized countries.

For the most part, firms tended to export occasionally to neighbouring countries, particularly those with a lower degree of industrial development. Exports were countercyclical, increasing when there was a drop in domestic demand or a depreciation of the exchange rate. The products exported were the same ones that the firms sold on the domestic market. The system of incentives was such that most consumer goods firms specialized in producing for the domestic market, protected from external competition.

When they managed to overcome the initial financial constraints and reached a certain production threshold, companies generally had relatively easy access to financial support from the government, which provided credit at low and often subsidized interest rates. This allowed them to continue expanding. Once they reached this stage, the pressures to increase productivity were not as strong as in the previous stage.

In addition, by the time the firm had established a manufacturing plant of an adequate scale for the dimensions of the domestic market, competitive pressures from similar domestic companies were considerably reduced. The small size of the domestic market often allowed it to be controlled by a limited number of firms engaged in collaborative behaviour, dividing it up into market shares which remained quite stable over time.
Therefore, once a typical consumer goods manufacturing firm had achieved a certain minimum production scale and a given share of the domestic market, it would reach a plateau. It was perfectly possible for the firm to continue operating in this way: with family-style management there were no strong pressures pushing the firm to continue evolving, and its environment became quite stable and safe.

The lack of strong competitive pressures, once the firm had passed a certain threshold, had repercussions on the way production was organized. Hence, while production was broadly organized following the guidelines used in industrialized countries, firms were not obliged to continue introducing changes to improve productivity and quality.

The import-substitution-based development model allowed the countries of the region to create a manufacturing sector. Without it, most of them would now have a substantially smaller number of industrial firms. This model made possible the learning and evolution that allowed a workshop to be turned into a manufacturing firm. It also helped to transform several generations of rural migrants into industrial production workers. Indeed, a substantial proportion of the manufactured goods the region exports nowadays comes from firms that exist thanks to import substitution industrialization policies. However, by the 1960s this model had become a constraint on the development of the Latin American countries (ECLAC, 1994).

Between the mid-1980s and the late 1990s, most of the countries in the region substantially transformed their macroeconomic and trade policies, as well as most of the regulatory environment. These changes had a considerable impact on firms in the region, altering the framework they were used to operating in and submitting them to strong competition from imports. 


\section{III}

\section{The behaviour of firms in the 1990s: Main findings}

\section{The influence of macroeconomic and trade policies}

What influence do macroeconomic and trade policies have on firms' behaviour? An examination of the differences in behaviour between firms in Chile, Mexico and Venezuela, and of the evolution within a given country over time, would be useful for assessing this influence.

Most Chilean firms had maintained or increased their production levels in the year that preceded the interviews, thanks to the general macroeconomic stability and sustained growth of Chile. This result was also due to the fact that the firms which had managed to survive the shock of the industrial restructuring that took place at the end of the 1970s and the beginning of the 1980s were relatively strong, even under the pressure of increased competition from imports.

Mexican firms displayed two types of behaviour. Most of them had suffered a sharp drop of up to 30\% in their output in response to the slow rate of growth of the Mexican economy up to 1993 and the increased import penetration. However, several firms which had invested heavily in upgrading and/or which exported had increased their output.

In contrast, most Venezuelan firms had suffered a sharp drop in output owing to the considerable decrease in demand resulting from the political uncertainty in the latter part of 1992 and very strong competition from imports.

Macroeconomic changes appear to have become even more important for manufacturing firms after trade liberalization. For example, appreciation of the exchange rate results in a substantial increase in competition from imports in a very short period of time.

Further evidence of the impact of macroeconomic trends on firms' behaviour is the evolution of exports by Chilean firms. While in 1990 several of the companies surveyed in that country belonged to a category that could be classified as having "moderate exports", regularly exporting between $5 \%$ and $10 \%$ of their output, by 1992 there were no firms in this category in Chile: either they had opted out of the export market completely or had substantially increased their export efforts and the percentage of output they exported. The growth of domestic demand, combined with an appreciation of the exchange rate, polarized the firms' export behaviour, causing most of them to focus exclusively on the domestic market, while those which wished to continue exporting had to become increasingly specialized in that market. This is illustrated by the fact that while, among Chilean firms interviewed in given sectors, the number of firms exporting decreased as the exchange rate appreciated, the average exports for those that habitually exported increased from $15.6 \%$ of their output in 1990 to $44 \%$ in 1992.

The fact that the evolution of the firms' output was heavily influenced by macroeconomic events in all three countries shows the importance of the macroeconomic environment for company behaviour.

Similarly, there is a clear link between export behaviour and the degree of openness of the economy: none of the Venezuelan firms visited were exporting at the time of the interviews (March 1993), whereas there were several exporting firms in Chile and even more in Mexico. These two countries had liberalized trade before Venezuela, and it was clear that there would be no reversal of this policy. Venezuela, on the other hand, had liberalized trade late in the 1980s but, at the time of the interviews, there were serious doubts that this policy would be sustained. The events which have taken place in Venezuela since then have proved that this was a correct assessment of the situation.

The strong influence of macroeconomic and trade policies on firms' behaviour means that the implications of these policies must be carefully evaluated. Similarly, the effects produced on firms' behaviour by uncertainty in respect of economic policy must also be taken into account. An example of this is what took place in Venezuela from 1993 on. 


\section{The margin for microeconomic behaviour}

However, in spite of the considerable influence of the economic environment on firms, the research also leads to the conclusion that there is a margin for company strategy: not all the Chilean firms were modernizers, not all the Venezuelan firms were going under.

Some firms can manage to be competitive in spite of an adverse environment and of being in a subsector where there is very strong competition from imports. One example of this are two Venezuelan firms that were willing to continue investing, training their personnel and to search for new survival strategies while most firms in that country were seeing their output drop and their market share dwindle owing to the recession and to competition from imports. These modernizing firms had gambled that they would survive and were following an active upgrading strategy in order to be competitive.

Another example can be seen in several Mexican industries characterized by particularly strong import penetration, such as the garment and shoe industries. While many firms in these industries had closed down, several surviving firms were doing remarkably well, thanks to their efforts to adapt to the new environment.

More research should be carried out on individual company strategies and the capability of some firms to learn and adapt to a new environment. There is much to be learnt from these firms, and knowing more about their strategy would be useful for policy design. Efforts should also be made to provide economic theory with a more solid theoretical framework for analysing the scope for microeconomic behaviour (Nelson, 1991).

\section{Changes in firms' behaviour}

The general behaviour of a manufacturing firm under import substitution, as described above, is still an accurate description of the behaviour of some firms today. However, the research led to the conclusion that the behaviour of many firms in the region is undergoing substantial change.

The interviews with company executives and private-sector representatives carried out during the investigation showed that the entrepreneurial environment is very dynamic and that changes are taking place. It is possible that many more transformations are occurring than can be perceived at an aggregate level, partly because some are still incipient and also because many of the changes are in conflicting directions.

In order to survive, manufacturing firms have been forced to adapt to their new environment. This has required substantial investments, which can be very costly given the limited availability of long-term financing, as well as the high interest rates that have prevailed in the region, particularly under stabilization policies.

From the information gathered during this investigation, what are the changes that may be observed in consumer goods manufacturing firms in Chile, Mexico and Venezuela today? The present section addresses this issue, first by describing the behaviour of most of the modernizing firms and then by concentrating on some specific areas where there have been major changes.

The modernizing firms are specializing: decreasing the number of production lines, while increasing the variety of goods manufactured within the production lines they maintain. They are decreasing the size of production batches and the time that it takes to produce them. They are also decreasing inventories, particularly those of final goods.

To achieve this, the companies are changing their layout, following the advice of external consultants that they hire themselves or that are contacted through foreign firms, such as clients or companies they have a licence from. The changes in layout are no longer conceived as something that will remain in place for a long time, but rather are implemented with flexibility and a willingness to adapt them regularly as changes in demand require.

The aim of the changes in layout is to facilitate the production flow and improve quality control. The introduction of automated control of the production flow also enables the firm to have precise information on individual worker productivity and to detect bottlenecks quickly.

The plants that are modernizing most successfully are those that have been able to systematically apply production standards and efficiency goals in line with Fordist practices. This has enabled them to increase productivity substantially. Production routines have also been modified to introduce more quality checkpoints and, in the most advanced plants, to increase individual worker responsibility for quality standards. With respect to whether flexible speciali- 
zation and greater worker autonomy are replacing Fordist practices, the research confirms the findings of a previous case study in the Brazilian shoe industry that "suggests that more important than the boundaries are the connections between Fordism and flexible specialization" (Schmitz, 1995).

Quality has also improved thanks to substantial upgrading of design capability as professional personnel are hired and automated equipment is put in place.

The desire to improve quality and to attain efficiency goals has led firms to modify payment systems. The changes implemented for this purpose, described below, indicate that firms are seeking payment systems that fit their need to upgrade productivity and quality standards.

The changes in the organization of production and in systems of payment are accompanied by changes in management practices, as firms pass from a family-based management style to one following professional guidelines. These changes are in response to the increasingly competitive environment, but they also often coincide with a generational transition as regards company ownership.

The following are the areas in which the most important changes are taking place.

\section{a) Vertical integration}

An illustration of changes in macroeconomic and trade policies resulting in changes at the microeconomic level is the degree of vertical integration within firms. High degrees of vertical integration were advantageous under import substitution policies because firms selling intermediate goods had considerable market power, particularly when they sold to firms that were rivals in the finished-product market. However, this is no longer the case, given the increased options for input procurement outside the country resulting from trade liberalization.

Indeed, the interviews in vertically integrated plants provided evidence that for many industries a high degree of vertical integration has gone from being an asset to a liability for firms, as it restricts their flexibility for input procurement. On several occasions, managers in charge of producing final goods complained about having to use inputs made within the same firm: an obligation that restricted their possibilities of purchasing a variety of inputs at low cost in a reasonable period of time. In most cases, it was not only cheaper for them to buy inputs outside the firm, but the delays involved were also reduced. Every one of the vertically integrated firms said that they were using increasingly small proportions of inputs produced within the same firm.

Plants manufacturing non-competitive intermediate goods have been particularly severely affected, since there has not only been a decrease in their production of inputs for plants within the same firm, but the demand for their goods from other firms within the country has plummeted. Quite often, unless they provide a very competitive input, vertically integrated plants are an obstacle to the flexibility which firms now need in order to be able to respond quickly to changes in demand.

Some companies have begun to address this issue by setting up different firms within a conglomerate and decreasing the obligations of their firms to buy inputs from related plants. In several cases, the move towards vertical dis-integration has gone even further as firms that were formerly integrated have separated into different firms with different owners. This allows firms to specialize in separate segments of the production sequence, gaining economies of scale.

\section{b) Utilization of imported inputs}

Along with the decrease in vertical integration there has been a significant change in input procurement, as firms in the three countries use increasing amounts of imported inputs. This was only to be expected after trade liberalization processes combined with currency appreciation. There was evidence of this in all three countries, as all firms had increased their use of imported inputs in the previous three years.

Chilean firms used higher percentages of imported inputs than their Mexican and Venezuelan counterparts. This is because trade liberalization started earlier in Chile than in the other two countries. It is also due to the small size of the economy, which limits the variety of inputs manufactured domestically.

For firms that were not vertically integrated, trade liberalization was an opportunity to buy a greater variety of inputs, often of better quality and at lower cost. The use of imported inputs has played an important role in firms' strategies aimed at becoming more competitive. 
c) Technology

A rough estimation of the technological level of the firms was made by comparing their equipment during the interviews with firm executives and visits to the plants.

The first finding is that when the technological level of firms in the same industry was compared across countries, the differences, surprisingly, were much smaller than would have been expected in view of the differences in the sizes of the economies. While it is true that some of the firms with the most advanced technologies were Mexican, the average gap between similar industries in the three countries does not seem to be very wide.

In contrast, there was wide dispersion of technological levels between firms in the same industry within the same country. This was the case in Chile, Mexico and Venezuela, and is evidence of the heterogeneity of Latin American industry. At least in traditional consumer goods manufacturing sectors, different technological levels seem to be able to coexist side by side. This dispersion appeared to be greater in Mexico than in the other two countries.

It was also surprising to find that, for large and medium-sized companies, there is no systematic correlation between the size of the firm and its technological level. Several of the largest firms interviewed had quite low technological levels, while some mediumsized firms had better equipment, as well as more modern management practices. This may be due to the fact that some large firms that are older and accustomed to operating in an import-substitution environment are addressing other issues, such as increasing flexibility and subcontracting, before introducing technological innovations.

Similarly, there does not appear to be any systematic correlation between investment in hard technology and company competitiveness. Several firms had relatively sophisticated equipment yet were not very competitive. For example, some firms, particularly in Venezuela, had relatively advanced equipment that they often did not use.

However, while a relatively high technological level does not necessarily mean that the firm is competitive, the reverse does seem to be true. More than the technological level they had attained, what seemed to characterize modernizing firms was their search for ways of raising their technological level by acquiring the specific equipment that would allow them to solve specific problems.
In other words, rather than expenditure on capital goods for the whole plant, what characterized modernizing firms was their efforts to "fine-tune" the incorporation of technology in the plant, and to do so systematically, on an ongoing basis.

\section{d) Incentive payment systems and management techniques}

In most firms in the region production workers are still paid on the basis of fixed wages that are a function of the time spent at the workplace and are often linked to the evolution of the minimum wage. Some firms also use piecework.

On the other hand, the goal of improving productivity and quality has led many firms to explore new pay systems. A growing number of companies interviewed in the course of the research are trying out new ways to pay production workers that can result in productivity increases. For example, most of the firms exporting a substantial proportion of their output were using new schemes of payment for their production workers which are innovative, at least compared with the usual practices in the region. Such schemes include incentives for attendance and highquality output, as well as productivity goals based on international industrial standards.

Efforts in this direction were most frequent in Mexico. Half of the firms interviewed in that country had innovative pay schemes in which attendance and quality incentives could amount to up to half the workers' monthly wage. The purpose was clearly to find the pay system that would best enable the firms to improve their productivity, as well as the quality of their products. There are even a few companies in Mexico which are paying an extra bonus in return for a worker's capability and willingness to work in different positions within the plant. Similarly, follow-up visits to Venezuelan firms at the beginning of 1995 showed that the most modernizing firms in that country were also training workers to carry out multipurpose tasks.

The companies that were introducing new ways of paying their workers were also among the most dynamic, as well as the most innovative in other areas, such as in the introduction of new management techniques. In fact, this last characteristic is almost a prerequisite for incentive payment schemes, since setting up more sophisticated pay systems than those generally used in Latin America requires procedures that allow careful monitoring of the productivity and 
quality of the work of individual employees. ${ }^{3}$ The managers of these modernizing firms say that one of their most important competitive advantages is precisely their human resources practices. While it is not yet obvious which of the systems are the most efficient, companies are clearly aware that improving productivity and quality requires innovations in incentive pay systems.

\section{e) Training}

Most of the firms interviewed in Chile and Venezuela provided very little training for their workers. This was particularly surprising in the case of the former country, since Chilean firms can obtain a tax credit to cover the cost of some training activities and entrepreneurs in that country stated that deficiencies in human capital were among the greatest competitive disadvantages they faced (Macario, 1995).

Mexican firms, on the other hand, appeared to be much more willing to spend resources on training their personnel, although, on average, the amount spent is quite small. Some of the companies interviewed even had small schools in the plant which provided not only specific training but also general education programmes.

Mexican companies' greater disposition to train their workers is partly due to a combination of the lower average educational level of the workforce and the various training programmes being offered by the government (Federal and regional).

However, the main explanation for Mexican firms' greater training efforts is their managers' desire to achieve a substantial increase in productivity to counter the competitive pressures they are facing. The companies that are investing most resources and energy in training are precisely those which are trying to overhaul their whole organization.

\section{f) Subcontracting}

When import substitution policies prevailed, there were a few firms in the region that subcontracted part of their production, but this tended to be the exception rather than a frequent practice. Most large companies were not under much pressure to reduce costs and they had a relatively stable market

\footnotetext{
${ }^{3}$ One of the innovations most frequently observed is the introduction of computerized systems that allow monitoring of the production flow and inventory control.
}

share. If new operations had to be carried out on a regular basis, they ended up being undertaken internally in the firm. Subcontracting was generally used only for very specialized tasks or for unexpected surges in demand.

The situation now appears to have radically changed, and one of the most noteworthy developments observed during the interviews was the remarkable increase in subcontracting by firms in the region. This is the result of changes that are occurring both at the global level and within the region. In the first place, there has been a considerable surge in international subcontracting as firms establish dynamic networks on a worldwide basis, thanks to the decrease in transportation costs and improvements in telecommunications (Dicken, 1992). At the same time, in Latin America the combination of trade liberalization processes and exchange-rate appreciation has exposed firms to very strong competition, forcing many companies to downsize and reduce costs. Subcontracting plays a key role in firms' survival strategies, allowing them to reduce their fixed costs and to respond more quickly to changes in demand.

Most of the companies interviewed had increased their subcontracting of manufacturing operations in recent years. Moreover, most of them expected subcontracting to increase substantially during the years to come. Some of them subcontracted the manufacture of products they had previously produced internally in the firm, but for which the production lines had been closed down. In other cases, firms had decided to centralize product design and subcontract most of the manufacturing process.

While an increase in subcontracting could have been reasonably foreseen even at the beginning of the investigation, the extent to which it is practiced in Chile, Mexico and Venezuela is quite striking. Not only has subcontracting within the same country become prevalent, but also many firms are subcontracting abroad. In some cases, companies subcontracted work to a firm in a neighbouring country which had a cheaper and better trained workforce, as in the case of the Venezuelan firms that subcontracted operations in Colombia. In other cases, companies decided to gain a competitive edge by going to the region that produced the goods responsible for taking away their market shares: in other words, they subcontracted directly in Asia.

This practice, which is being adopted in a large variety of sectors, is particularly widespread in gar- 
ment and footwear manufacturing. Rather that letting themselves be displaced from Latin American markets by Asian products, firms have decided to subcontract at least some production lines directly in Asia.

While some companies have gone all the way, practically shutting down domestic production and concentrating instead on distribution, most firms have reacted in a way that will allow them much more flexibility in the long run: they subcontract production in those lines in which they are less competitive, while trying to become very competitive in the lines they retain. In this way, if there are changes, such as a depreciation of the exchange rate, they will still have manufacturing capabilities and can then increase domestic production. Meanwhile, this strategy allows them to defend their share of the domestic market, especially in view of exchange-rate appreciation and the remarkable surge of low-cost Asian exports of increasingly high quality.

This practice is much more widespread than is publicly perceived. Entrepreneurs are reluctant to mention it (more so in Mexico and Venezuela than in Chile) because they fear a negative reaction. Another reason is that many trade associations are demanding government protection against what they claim to be unfair competition from Asian products. Entrepreneurs are also reluctant to reveal what is one of the key elements of their competitive strategy. But the fact is that the most competitive firms in the region are following this strategy, which is really a very reasonable one, since it allows the company to survive and to concentrate on manufacturing the products in which it is competitive.

\section{g) Distribution and retailing}

For most manufacturing industries, distribution and retailing did not play a key role when import substitution policies aimed at creating a domestic industrial sector prevailed. Productive activities were favoured over distribution, and it was much easier to obtain subsidized credit to set up an industrial plant than for retail outlets. Furthermore, industrial manufacturers had substantial market power over retailers, who did not have much choice in purchasing their merchandise. Hence, production was emphasized rather than retailing. Even though manufacturers often distributed their own goods directly to consumers, the core of the manufacturing business was the plant itself.

Nowadays, circumstances have changed dramatically for most of the traditional consumer goods manufacturing industries. By opening up their economies, the Latin American countries have given their consumers the possibility of choosing among a wide variety of goods. Import penetration is very strong, and retailers are no longer restricted to goods produced domestically. This has produced a shift in manufacturers' activities.

This shift became obvious in the course of the investigation in Chile, Mexico and Venezuela. Most of the executives of modernizing firms said that their main concern was to become competitive in distribution and to achieve name recognition for their brand. They said that this was the single most important factor for the survival of their manufacturing activities, as the market was flooded with goods from other countries.

Because of this, simultaneously with the decrease in the degree of backward vertical integration there has been a substantial increase in investment to increase forward integration: many manufacturing companies believe that ensuring the presence of their brand in the domestic market and securing a strong retail structure will increase their possibility of surviving as a firm.

While this situation was noted in all three countries, it was most evident in Chile. Almost all of the company executives interviewed in that country said that ensuring a good retailing system was of the uppermost importance to them. Sometimes the company itself owned retail stores, sometimes it did not, but at all events retailing is a crucial aspect of company strategy.

While this situation was also observed in Mexico and Venezuela, it was not as prevalent there as in Chile. This is because the relatively small size of the Chilean domestic market makes capturing a market share more important. It is also due to the fact that Chile liberalized foreign trade before Mexico and Venezuela, and many Chilean firms were forerunners in recognizing the importance of retailing for manufacturing company strategy.

Whatever the main reason may be, the fact is that although the trend was much more marked in Chile, the importance of establishing solid distribution networks was also a key element of the strategies of the most competitive firms interviewed in Mexico and Venezuela. One Venezuelan company executive, who runs a very interesting, innovative firm, said: "If I had any investment resources available, I would open new stores". Similarly, the Chief Executive Officer of 
the Mexican firm that was among the best-organized manufacturing plants visited believes that his greatest competitive disadvantage is his lack of forward integration.

Another indication of the importance of this trend is the fact that many companies that were making investments were actually concentrating most of the resources on improving the distribution of the firm's products, rather than on manufacturing itself. In fact, technological innovations, such as on-line sales and stock control, were often introduced with that purpose. Similarly, companies frequently tend to focus training efforts on their marketing employees, rather than on production workers.

Moreover, a strong distribution network also allows manufacturers to distribute imported goods, thus defending the market share of their own brand. This provides them with the opportunity to have some control over the prices at which competing imports are sold, as well as making profits on their own sales. This strategy appears to be very sound from the manufacturer's point of view, as it allows firms to benefit from import surges and to continue manufacturing the product lines in which they are still competitive, while at the same time retaining their market share.

\section{h) Exporting firms}

What were the differences observed between modernizing firms in general and those that regularly exported a significant proportion of their output (over $15 \%$ or $20 \%)$ ?

In terms of sales and employment, the exporting firms included in the investigation were quite similar to those that exported only occasionally, those that regularly exported a small percentage of their output and those that did not export at all. While exporting firms tended to have slightly higher employment and sales levels than non-exporting firms, the differences were not significant between the two groups, for a given industry.

There does appear to be a minimum sales threshold beneath which it is difficult to find firms that export regularly. This is probably due to the fixed costs involved in exporting, such as purchasing equipment that enables the firm to achieve better quality, acquiring clients abroad, and carrying out the paperwork required to export. But above a certain level there no longer seems to be a systematic correlation between company size and export activity: while in a given industry most exporting is indeed carried out by large firms, there are medium-sized firms that export and many large firms that do not export at all. The growing number of medium-sized Latin American firms that are exporting is an interesting phenomenon that deserves further study.

However, the one significant difference between exporting and non-exporting firms was the greater concern that the former have for quality improvement. Exporting firms are increasingly exporting goods manufactured according to export-market specifications, instead of simply exporting goods identical to those they sell on the domestic market. The importance of quality for exporting firms was reflected in plant layout specifications, as well as training and wage incentive systems. Exporting firms provided training more frequently than non-exporters and tended to have introduced more innovations in wage systems.

Exporting and selling on the domestic market should not necessarily be viewed as involving a trade-off. In fact they can often be interrelated choices, particularly in small economies such as Chile. It may be that a firm needs to export in order to attain the scale that allows it to be competitive in the domestic market. Exporting also provides learning opportunities for firms, as they learn how to satisfy requirements in more demanding markets. This learning has a positive spillover effect in the domestic market. At the same time, a solid position in the domestic market allows a firm to bear the cost of going into new export activities.

The investigation leads to the conclusion that in traditional consumer-goods industries there are no significant differences between large and mediumsized modernizing firms that focus mainly on the domestic market and exporting firms. The only exceptions are the importance of quality for exporting firms and the learning opportunities provided by exporting. It may be said that in general exporters are modernizers, but not all modernizers are exporters.

\section{Flexibility}

The previous sections described how the most innovative consumer-goods manufacturing firms in Chile, Mexico and Venezuela are undergoing important changes in the way production is organized, in vertical integration and input procurement, as well as in management style and in wage systems, among other 
features. Companies are adapting and learning how to be competitive in the new economic environment prevailing in the Latin American countries.

Rather than a massive once-for-all overhaul of the firm, however, the most relevant characteristic of these innovating companies is the flexibility they display in continuously improving their performance, for example thanks to the ability to pinpoint the areas where bottlenecks are most severe. Transformations are now carried out on an ongoing basis, sometimes through a series of small changes. These transformations finally result in a massive overhaul of production practices, but of a different nature from that achieved through a once-and-for-all effort.

The importance of such flexibility should not be underestimated, both in production and in distribution: firms that have the highest success rate (and the highest survival rate in the face of very adverse shocks, such as some companies in Venezuela) are those that are able to react quite rapidly and adapt to new circumstances.

For example, one of the areas where flexibility is clearly important is in enabling firms to develop more adaptable production systems that allow them to react to changes in consumer demand and to produce a wide variety of goods with a limited number of production lines. Changes in production are increasingly demand-led, and the time it takes for firms to introduce changes in response to changes in demand has decreased.

Another area in which flexibility is critical is the ability of firms to react to changes in the exchange rate, retaining a minimum production capability that enables them to cover their market share, while being willing to transform themselves rapidly into distributors of some lines of imported goods when there is a substantial appreciation of the exchange rate. The strategy of becoming the main importers of goods competing with their own products and distributing them through their own distribution channels was one of the strategies hesitantly adopted by a few firms in Chile in the late 1970s and early 1980s. In retrospect, we can now see that this strategy was to become very successful.

Entrepreneurs have learnt from this past experience, and the most successful and resilient firms in the three countries are those that have the flexibility to convert themselves rapidly into importers and distributors of competing imported goods. They have realized that this is the best way to be able to manage prices and to set prices of imported versus domestically produced goods, according to their production capabilities. This strategy allows the firm to use its own distribution channels, while continuing the production of its most competitive goods. Behind this strategy is the idea that if the company does not do this, another firm will seize the opportunity and displace it from the market.

However, while becoming distributors of imported goods is a strategy that is increasingly being put into practice by enterprising Mexican and Venezuelan manufacturers, and continues to be practiced by the Chilean ones, it is not always readily acknowledged by them, since they are reluctant to admit that they are becoming major importers of competing goods.

\section{The shift in the core of the manufacturing business}

In addition to the importance of flexibility for company strategy, another important feature of the changes that are occurring in companies' behaviour is the shift in what constitutes the core of their strategy.

Under import substitution, manufacturing firms had a relatively advantageous position with respect to distributors and retailing firms: they could obtain credit at preferential rates and special permits to import inputs, and they could lobby to stop imports of competing goods once they had set up local production facilities, among many other advantages. Although some manufacturing firms were also retailers, the core of the manufacturing business was production.

Today, the situation for Latin American manufacturing firms is radically different. They face vigorous competition in the domestic market, both from imports and from other domestic firms that are trying to defend their market share. Consumers have also grown more demanding as they have had access to a wider variety of goods, not only as a result of trade liberalization, but also because of exchange-rate appreciation.

A competitive manufacturing firm now not only has to upgrade its organization of production but must also have an active and aggressive retailing strategy. Trade liberalization, particularly in a context of currency appreciation, has significantly increased the importance of distribution and retailing. The most innovative manufacturing firms studied in the survey 
TABLE 1

\section{Summary of strategies used by manufacturing firms in the 1990 s}

\begin{tabular}{|c|c|c|}
\hline & Modernizing firms & Non-modernizing firms \\
\hline \multirow[t]{9}{*}{$\begin{array}{l}\text { Areas in which differences } \\
\text { are highly significant }\end{array}$} & $\begin{array}{l}\text { Flexibility in the continuous introduction of changes } \\
\text { in production and distribution in response to changes } \\
\text { in demand and in the macroeconomic environment } \\
\text { (such as the exchange rate) }\end{array}$ & Rigid passive behaviour \\
\hline & Hiring of external consultants for upgrading & Exclusive reliance on in-house expertise \\
\hline & Productivity is continuously measured & Productivity data not available \\
\hline & Innovative incentive payment systems & Traditional wage systems \\
\hline & Professional management & Family-based management \\
\hline & Production changes are demand-led & $\begin{array}{l}\text { Limited changes in response to } \\
\text { production concerns }\end{array}$ \\
\hline & $\begin{array}{l}\text { Large increases in subcontracting based on long-term } \\
\text { relationships }\end{array}$ & $\begin{array}{l}\text { Subcontracting is nonexistent or very } \\
\text { limited }\end{array}$ \\
\hline & Strong interaction between production and distribution & Firm focuses exclusively on production \\
\hline & $\begin{array}{l}\text { Whenever possible, closer ties with retailers or significant } \\
\text { increases in retailing carried out by the firm itself }\end{array}$ & Loose ties with retailers \\
\hline \multirow[t]{12}{*}{$\begin{array}{l}\text { Areas in which differences } \\
\text { are significant }\end{array}$} & $\begin{array}{l}\text { Substantial decrease in vertical integration: } \\
\text { related plants become independent firms }\end{array}$ & Decrease in vertical integration \\
\hline & Significant increase in the use of imported inputs & Increase in use of imported inputs \\
\hline & Efforts to improve design capability & Limited design capability \\
\hline & Reduction in stocks & Large stocks maintained \\
\hline & Regular changes in production layout & Rigid process layout \\
\hline & Reduction in the number of production lines & Number of production lines maintained \\
\hline & Increased product diversity within production lines & $\begin{array}{l}\text { Limited product diversity within } \\
\text { production lines }\end{array}$ \\
\hline & Quality is important & Quality is not a priority \\
\hline & Individual worker responsibility for quality & $\begin{array}{l}\text { Quality control at a few points on the } \\
\text { assembly line }\end{array}$ \\
\hline & $\begin{array}{l}\text { Technological innovations are introduced at key points, } \\
\text { after thorough assessment of existing bottlenecks }\end{array}$ & $\begin{array}{l}\text { If introduced, technological innovations } \\
\text { are bought in a package, not in } \\
\text { response to a careful assessment of } \\
\text { the plant's strengths and weaknesses }\end{array}$ \\
\hline & $\begin{array}{l}\text { Technological innovations are introduced regularly on a } \\
\text { continuous basis }\end{array}$ & $\begin{array}{l}\text { Technological innovations are introduced } \\
\text { on a once-and-for-all basis }\end{array}$ \\
\hline & The firm provides training for its workers & The firm does not train its workers \\
\hline
\end{tabular}

RESTRUCTURING IN MANUFACTURING: CASE STUDIES OF CHILE, MEXICO AND VENEZUELA • CARLA MACARIO 
were those that had a network of retailing outlets, with the goal of preserving their share in the domestic market and benefiting from the sale of imported goods. Retailing also allows manufacturing firms to increase their profit margins, since it is in essence a non-tradeable activity in which profit margins have soared in recent years. It also allows firms to manage flexibly a product mix of goods manufactured in their own plants and imported goods, depending on the evolution of the exchange rate.

The follow-up interviews with Venezuelan firms in 1995 showed that the most competitive firms were putting into practice a strategy of decreasing the amount of goods they sold to intermediaries and increasing the proportion of goods they retailed themselves. Executives of these firms said that the key survival strategy for their firms was to improve the distribution network and retail most of the products themselves.

The transformations in the way the Latin American economies integrate into world markets have had significant consequences for manufacturing firms' behaviour. Manufacturing firms need to upgrade their supply capabilities in response to changes in demand. However, in order to be able to carry out this upgrading, which is crucial for their survival, manufacturing firms must first be able to defend their presence in the market. What has changed as a result of trade liberalization, globalization and the transformations in the firms' economic environment is precisely the core of the manufacturing business: in order to survive and become competitive, manufacturing firms must now improve their marketing capabilities, and in order to do this they must transform their supply capabilities.

\section{Uncertainty}

Macroeconomic stability and certainty that economic policy would be sustained were among the most important positive characteristics of the economic environment mentioned by Chilean and Mexican entrepreneurs during the interviews. These were carried out in 1993, before the Mexican crisis that began with the December 1994 devaluation.

In contrast, for the Venezuelan firms interviewed in 1993 one of the main obstacles to investing in upgrading and in export projects was the uncertainty surrounding the country's economic policies. This was confirmed by the follow-up interviews with
Venezuelan firms in 1995, which showed that companies which had pursued active upgrading policies were either in an extremely vulnerable position or bankrupt, while those which had adopted a passive attitude had benefited from their decision not to upgrade.

The specific cases of the two largest garment manufacturers interviewed in Venezuela, hereafter called firm A and firm B, illustrate this. When the first interviews took place (March 1993), these two firms had decided to adopt two distinctly different strategies: firm A had decided that it would continue operating largely the same way it had operated under import substitution and that it would not invest in upgrading production capability, nor in improving the quality of the goods it manufactured. This conservative strategy was also adopted for exports, in which the firm decided it would not invest any resources.

Firm B, on the other hand, had decided to invest a substantial amount of resources in a complete upgrading of the firm's production capability, both in terms of the quality of the goods produced and the volume of production. To achieve this, it hired international consultants who redesigned the plant and trained the employees. Simultaneously, technological innovations were introduced as new equipment was purchased and production procedures were transformed. The company's goal was to cope with the strong competition from imports in the domestic market and then continue to expand its markets by exporting.

At the time of the initial interviews, it seemed that firm A would slowly die owing to increased import competition and its inability (or the lack of interest of its owners) to react to the change from an import substitution model to an open economy. In contrast, it appeared that the strategy of firm B would allow it to become competitive in the new environment, to survive import competition in the domestic market and to export on a regular basis.

When the follow-up interviews were carried out two years later, in 1995, however, circumstances were strikingly different. The new government of Venezuela had decided to reverse several of the policy reforms carried out at the end of the 1980s and the beginning of the 1990s. While the trade liberalization policy was not formally reversed, this did occur in practice because of exchange controls that made it difficult for firms to have access to hard currency for imports, including inputs. Competition 
from imports had thus been slashed. Furthermore, the pegging of the exchange rate at a time of high inflation made it extremely difficult for manufacturing firms to export.

In these circumstances, firm $\mathrm{A}$ had been relatively successful thanks to its decision not to invest in upgrading the plant. This strategy had allowed the firm to maintain a solid financial position without incurring debts. It had proved successful because changes in economic policy, such as the introduction of exchange controls, had resulted in a substantial decrease in competition from imports, while at the same time interest rates went up. Thus, firms that had adopted a passive attitude and had decided not to change their strategy and not to upgrade benefited from the decreased import competition in the domestic market and from a sound financial position.

In contrast, companies which had invested in upgrading their production capability were hurt by the increase in interest rates. Firm B, for example, was in severe financial difficulties, having incurred debts to finance the upgrading. Although it was still able to export, exports had been curtailed by the obstacles to importing good-quality competitive inputs, such as exchange controls and the appreciation of the exchange rate. Complex and discretionary administrative procedures also made importing and exporting very difficult. Hence, firms that had invested in upgrading and had tried to become competitive were ultimately losers compared to those that had adopted a passive attitude.

It is clear that in the long run this situation will not last. Venezuela cannot support an artificial exchange rate forever, nor will it always be able to sustain policies that tend to limit competition from imports. Venezuelan firms will eventually find themselves in a competitive environment once again, and in those circumstances firm A will clearly be forced to change or it will lose a substantial amount of market share, while firm B will reap the benefits of its investments.

In the meantime, firm B will undoubtedly gain a bigger market share even if the economy does not open up, thanks to its upgrading efforts. When interviewed in 1995, this company was also gaining market share because so many domestic firms were failing. The question is whether firms that invested in upgrading will still be operating in the long run or whether they will go under because of the financial burden of upgrading and the reversal of economic policy.
Thus, the managers who had believed the government's declarations that trade liberalization would be sustained and that they should invest in export projects were those whose firms were most severely damaged by the policy reversal. The appreciation of the exchange rate that resulted from the exchange controls and the pegging of the currency within an inflationary process made their exports less competitive on foreign markets. The obstacles to importing inputs caused by the exchange controls and customs red tape were an additional difficulty for those firms which had increased the use of imported inputs as one of their upgrading strategies.

Therefore, the interviews carried out throughout the investigation show that uncertainty over economic policy leads to a substantial decrease in company investment. There is no incentive for firms to invest in long-term projects when policy reversals and macroeconomic instability render the rate of return unpredictable.

Comparison of the behaviour of firms in the three countries covered by the research shows that uncertainty explains why more firms do not change, or do not change faster. Uncertainty has a twofold negative effect on entrepreneurs' decisions to transform their firms: they are uncertain as to what they should do, and also about the sustainability of economic policy. They are often aware that they must alter the way their firms operate, but they are not certain what changes should be made, or how. This shows the importance of providing companies with technical support on best practices through public/private sector networks. However, the uncertainty that probably has the most negative impact on firms' decisions concerning upgrading is whether trade liberalization will be sustained or not. If the policy in this respect is not completely credible, many firms will be reluctant to change their behaviour, and this indecision can result in many more firms going under than could reasonably have been expected.

Hence, it is of the utmost importance that major policy changes should be credible, if firms are to change their behaviour and try to become more competitive. It may reasonably be concluded that, if there is uncertainty, most firms will not change, or will not change so quickly. Upgrading requires a willingness on the part of company managers to change their firms' practices and to make heavy investments, as well as the certainty that the new policies are there to stay. 


\section{IV}

\section{Conclusions}

Manufacturing firms in Latin America are undergoing substantial transformations in order to be competitive in the new conditions marked by trade liberalization, globalization and, in general, changes in the economic environment. Many firms still have a passive or reactive attitude, with behaviour quite similar to that described in section II. However, the overwhelming majority of entrepreneurs in the region are aware that they must change the way they operate and have already begun to do so: the behaviour of most companies is completely different now from what it was 10 or 15 years ago.

These changes in companies' behaviour are strongly influenced by the transformations in macroeconomic and trade policies, as well as in the general economic environment. Evidence of this may be seen from the differences in firms' behaviour across countries.

However, the study showed that there were firms in all three countries which were changing their behaviour irrespective of the economic environment, adopting particularly innovative and aggressive strategies. While Venezuelan firms on average tended to be more passive and reluctant to change than their Chilean and Mexican counterparts, the most competitive Venezuelan firms had strategies that were surprisingly similar to those of the most aggressive firms in Chile and Mexico. Much may be learnt from the behaviour of these firms, particularly for the formulation of policy recommendations.

In general, there were no differences between exporting firms and modernizing firms that sell mostly on the domestic market, except that exporting firms seemed to have much greater concern for quality upgrading and had greater learning opportunities than non-exporting ones. The investigation did show, however, that modernizing the firm was a condition for sustained export activity.

The transformation that has taken place in what is seen as the core of the manufacturing business was one of the most significant results of the research. At least for the most innovative consumergoods manufacturing firms, this core has shifted from concentration mainly on production matters to an approach which combines the manufacture of goods with their distribution, and often the distribution of other domestic and imported goods as well. This is the point in the production/distribution segment where manufacturing firms have greater chances of simultaneously increasing their profits and defending their market share. Whatever strategy allows firms to be successful at this crucial point will be a decisive factor in determining the competitiveness of Latin American manufacturing firms in the years to come.

The changes that are taking place in the economies of the region have had significant consequences for Latin American manufacturing companies and have brought about substantial changes in their behaviour. Finding out more about these changes is a prerequisite for understanding trends, as well as for making policy recommendations aimed at improving company competitiveness.

Innovative firms have adopted a flexible type of behaviour and are upgrading their production and marketing capabilities. They have made significant changes in terms of vertical integration, input procurement, technological innovations, incentive payment systems, management techniques, training and subcontracting, as well as in distribution and retailing.

However, even modernizing entrepreneurs frequently felt that they needed to make even more effort to upgrade their firms. The cost of doing so and, more importantly, the difficulties in obtaining appropriate information on the best practice in a given industry, have been obstacles to the introduction of large-scale transformations in a short period of time. These obstacles were naturally even greater for non-modernizing firms, whose managers knew they had to change the way they operated, but were uncertain about what needed to be done and how. While some entrepreneurs in the region will remain passive and will continue operating as they did under import substitution as long as they can, there are many managers who would like to upgrade their firms but lack the necessary information for doing so. 
This suggests that governments have an important role to play in giving support to programmes that provide firms with information on best practices, particularly in matters relating to changes in layout, quality improvement, incentive payment systems, training, etc. A key activity that yields many positive externalities is providing firms with information on export markets.

An effective way of supplementing inadequate information is through setting up industry-specific technological centres to promote the upgrading of firms' supply capability. These centres should cover the areas in which innovation is crucial, such as those described above. Governments should sponsor such centres, but they should be created jointly with the private sector, particularly with entrepreneurial associations. These centres could also foster associations in which firms could join together to obtain better conditions for input procurement, technical assistance and distribution than they could obtain individually. A good example of such a centre is that established in Colombia by the Asociación Colombiana de Industrias Plásticas (ACOPLASTICOS), or the Centro de Productividad Industrial (CEPRI) recently set up in Chile by the private sector with government support.

Finally, there are several important criteria that must be taken into account when considering policy formulation: i) The most important role for policy is that of creating a stable economic environment in which firms can plan long-term investments. As already noted, uncertainty promotes non-productive behaviour;

ii) Policies should be designed for effective implementation and should be subject to regular evaluation. If not, they may prove ineffective and give rise to private-sector distrust of the government;

iii) Policies should explicitly seek to promote the upgrading of firms and not be a disguised pretext for a return to protectionism;

iv) To be effective, policies should be designed and implemented in close coordination with the private sector.

The new economic framework existing in most Latin American countries today, together with the increase in globalization worldwide, represents both a challenge and an opportunity for most manufacturing firms in the region. Many firms have already completely transformed their behaviour. Others will not change, irrespective of the policy environment they are in. There is a third group, however, made up of the vast majority of manufacturing firms, whose managers are willing to change and have begun to make some changes. This is the group that economic policy should target if the goal is for the region to have the capacity to grow at reasonably high rates.

(Original: English)

\section{Bibliography}

Baumann, R. (1994): Exporting and the Saga for Competitiveness of Brazilian Industry: 1992, Working Paper No. 27, Santiago, Chile, Economic Commission for Latin America and the Caribbean (ECLAC).

Bielschowsky, R. (1994): Two Studies on Transnational Corporations in the Brazilian Manufacturing Sector: The 1980s and Early 1990s, "Desarrollo Productivo" series, No. 18, Santiago, Chile, ECLAC.

Castillo, M., M. Dini and C. Maggi (1994): Reorganización industrial y estrategias competitivas en Chile, LC/R.1467, Santiago, Chile, ECLAC.

Corbo, V. and J. M. Sánchez (1984): Impact on Firms of the Liberalisation and Stabilisation Policies in Chile: Some Case Studies, Documento de trabajo, No. 91, Santiago, Chile, Catholic University of Chile, Instituto de Economía.

Dicken, P. (1992): Global Shift: The Internationalization of Economic Activity, London, Paul Chapman Publishing Ltd.
ECLAC (1994): Reestructuración y desarrollo productivo: desafío y potencial para los años noventa, "Estudios e Informes de la CEPAL" series, No. 92, LC/G.1831P, Santiago, Chile. United Nations publication, Sales No. S.94.II.G.4.

Katz, J. and G. Burachik (1997): La industria farmacéutica y farmoquímica argentina en los años noventa, in J. Katz (ed.), Apertura económica y desregulación en el mercado de medicamentos, Buenos Aires, ECLAC/International Development Research Centre (IDRC)/Alianza Editorial.

Macario, C. (1995): Competitividad de las empresas latinoamericanas: comportamiento empresarial $y$ políticas de promoción de exportaciones, Documento de trabajo, No. 38, Santiago, Chile, ECLAC.

- (1998a): Restructuring in Manufacturing: Case Studies in Chile, Mexico and Venezuela, "Desarrollo Productivo" series, No. 44, Santiago, Chile, ECLAC. 
- (1998b): Why and How do Manufacturing Firms Export: Evidence from Successful Exporting Firms in Chile, Colombia and Mexico, Ph.D. thesis, Columbia, Missouri, University of Missouri.
Nelson, R. R. (1991): Why do firms differ, and how does it matter, Strategic Management Journal, vol. 12, New York, John Wiley \& Sons, Ltd.

Schmitz, H. (1995): Small shoemakers and Fordist giants: Tale of a supercluster, World Development, vol. 23, No. 1, Oxford, U. K. 